\title{
Molecular Identification and Mycotoxin Production by Alternaria Species Occurring on Durum Wheat, Showing Black Point Symptoms
}

\author{
Mario Masiello ${ }^{1, *(\mathbb{D}}$, Stefania Somma ${ }^{1} \mathbb{D}$, Antonia Susca ${ }^{1}{ }^{\mathbb{D}}$, Veronica Ghionna ${ }^{1}$, \\ Antonio Francesco Logrieco ${ }^{1}$, Matteo Franzoni ${ }^{2}$, Stefano Ravaglia ${ }^{2}$, \\ Giuseppe Meca $^{3}$ and Antonio Moretti ${ }^{1, *(D)}$ \\ 1 Institute of Sciences of Food Production, National Research Council (CNR-ISPA), Via Amendola 122/O, \\ 70126 Bari, Italy; stefania.somma@ispa.cnr.it (S.S.); antonella.susca@ispa.cnr.it (A.S.); \\ veronica.ghionna@ispa.cnr.it (V.G.); antonio.logrieco@ispa.cnr.it (A.F.L.) \\ 2 S.I.S. Società Italiana Sementi S.p.A, Via Mirandola 1, 40068 San Lazzaro di Savena (BO), Italy; \\ teofranzo@gmail.com (M.F.); s.ravaglia@sisonweb.com (S.R.) \\ 3 Department of Preventive Medicine, Nutrition and Food Science Area, University of Valencia (Spain), \\ Avenida Vicent Andres Estelles s/n, Burjassot, 46100 Valencia, Spain; giuseppe.meca@uv.es \\ * Correspondence: mario.masiello@ispa.cnr.it (M.M.); antonio.moretti@ispa.cnr.it (A.M.)
}

Received: 29 January 2020; Accepted: 20 April 2020; Published: 23 April 2020

check for updates

\begin{abstract}
Black point is a fungal disease of wheat, mainly associated with mycotoxigenic Alternaria species. Affected wheat kernels are characterized by dark brown discolouration of the embryo region and reduction of grain quality. Potential risk is the possible accumulation of Alternaria mycotoxins, alternariol (AOH), alternariol-monomethyl ether (AME), tenuazonic acid (TA), and altenuene (ALT), provided by haemato-toxic, genotoxic, and mutagenic activities. One hundred and twenty durum wheat samples belonging to 30 different genotypes grown in Bologna and Modena areas, in Italy, showing black point symptoms, were analyzed for Alternaria species and their mycotoxin contamination. Alternariol was selected as an indicator of the capability of the Alternaria species to produce mycotoxin in vivo in field conditions. The data showed that Alternaria species occurred in 118 out of 120 wheat kernels samples, with the incidence of infected kernels ranging between $1 \%$ and $26 \%$. Moreover, $\mathrm{AOH}$ was detected by using a HPLC with a diode array detector (LC-DAD) in 98 out of 120 samples with values ranging between 24 and $262 \mu \mathrm{g} \mathrm{Kg}^{-1}$. Ninety-two Alternaria representative strains, previously identified morphologically, were identified at species/section level using gene sequencing, and therefore were analyzed for their mycotoxin profiles. Eighty-four strains, phylogenetically grouped in the Alternaria section, produced $\mathrm{AOH}, \mathrm{AME}$, and TA with values up to $8064,14,341$, and $3683 \mu \mathrm{g} \mathrm{g}^{-1}$, respectively, analyzed by using a LC-DAD. On the other hand, eight Alternaria strains, included in Infectoriae Section, showed a very low or no capability to produce mycotoxins.
\end{abstract}

Keywords: alternariol; alternariol-monomethyl ether; tenuazonic acid; altenuene; section Alternaria; section Infectoriae; species specific-primers

Key Contribution: The paper underlines the potential of the occurrence of black point symptoms on wheat and the possible risk of Alternaria species infection and their mycotoxin contamination in the kernels. In addition, the paper reports the characterization by a polyphasic approach of the different Alternaria species occurring on wheat, and the PCR protocol set up for the rapid detection of non mycotoxin producing Alternaria species, belonging to Infectoriae section. 


\section{Introduction}

Wheat is a largely cultivated crop worldwide in temperate areas, and is a stable food for humans, and also a basic component of the diet of livestock. In Italy, wheat has a production of about 8 million tons of durum (Triticum durum) and soft (Triticum aestivum) wheat, on a surface of about 1.8 million hectares [1].

Fungi are responsible for major wheat diseases such as black point, a worldwide disease of kernels, caused by a complex of species including mainly Alternaria species and Cochliobolus sativus [2-4]. Moreover, other fungi belonging to Aspergillus, Cladosporium, Curvulavia, Fusarium, Penicillium and Stemphylium genera can participate in the disease complex and all together these species can induce the expression of the symptoms of black point [5-7].

Among these genera, Fusarium and Alternaria associated with wheat kernels, are especially worrisome since they are able to produce mycotoxins $[7,8]$, toxic secondary metabolites that can be accumulated in colonized tissues [9]. Indeed, the mycotoxin contamination of wheat is one of the most important issue for human and animal health at the worldwide level, since, at harvest, a wide range of toxigenic Alternaria and Fusarium species can accumulate several mycotoxins in the kernels. Such infections, beside causing productive and economic losses with serious adverse impacts on the farmer's incomes, could lead to a serious risk for human and animal consumption, due to their toxic effects on several biological activities [10,11].

Alternaria is a ubiquitous and abundant fungal genus widespread in the atmosphere as well as in soil, seeds, and agricultural commodities. It includes plant pathogenic and saprophytic species that may affect crops in the field or can cause harvest and postharvest decay of plant products [9].

The main Alternaria species reported as associated with black point disease are A. alternata, A. tenuissima, A arborescens, A. infectoria [4,7,12-14]. Moreover, at a lower frequency, minor Alternaria species belonging to Infectoriae [15,16] and Pseudoalternaria sections [17] were also detected on wheat $[7,18,19]$.

Overall, the identification at species level is very difficult in this genus since most Alternaria species exhibit a considerable morphological plasticity that is dependent upon cultural conditions, substrate, temperature, light, and humidity [20]. In addition, several isolates have intermediate species traits that do not clearly segregate into recognized species [21-23].

Therefore, for a correct identification at the species level, a poly-phasic approach, based not only on morphology, but also on mycotoxin profile, and molecular characterization is worthwhile [24]. Among the most common Alternaria mycotoxins, there are the dibenzopyrone derivatives alternariol $(\mathrm{AOH})$, alternariol mono-methyl ether (AME) and altenuene (ALT) from one side; the tetramic acid derivative Tenuazonic Acid (TA), from the other.

The toxicological risk of $\mathrm{AOH}$ and AME has been elucidated by Da Cruz Cabrala et al. [25] that demonstrated their genotoxic activity on human cell lines of colon cancer. In addition, TA induces the human hematologic disorder called "onalay" and precancerous changes in the esophageal mucosa of mice [26]. Finally, for altenuene, acute toxicity has been reported [27].

Several studies reported the occurrence of Alternaria species on cereals worldwide, and the capability of Alternaria strains to synthetize wide contents of mycotoxins in in vitro media, but few studies reported the occurrence of mycotoxins on wheat and cereal foodstuffs. Recently, Romero Bernal et al. [28] reported high AOH, AME and TA contaminations of wheat and wheat derivatives, in Argentina, among which TA was the main mycotoxin detected. In a previous study, Azcarate et al. [29] reported that about $20 \%$ of Argentinian wheat samples were highly contaminated with Alternaria toxins, with a significant $\mathrm{AOH}$ content. On the other hand, a natural occurrence of ALT, AME and TA in wheat samples collected in different areas of China, Sweden and Albania was reported [30-32]. In addition, recently, $\mathrm{AOH}$ has been described as a virulence and colonization factor during apple, citrus, and tomato infection by Alternaria alternata [33]. Therefore, to detect the presence of Alternaria toxins in wheat and accurately identify the species that produce them is an important step for better 
evaluating not only the toxigenic risk associated with infected kernels, but also to understand if such metabolites are produced in the field during the infection process.

Although the genus Alternaria is considered an important wheat colonizer able to produce the abovementioned mycotoxins in vivo, the occurrence of Alternaria mycotoxins in cereals has been largely neglected for long time. This is probably due also to the lack of legislation on Alternaria mycotoxin occurrence in commodities. On the other hand, very poor studies have been devoted to evaluate the susceptibility of wheat to black point disease, have for many years considered only a problem for the quality and nutritive decline of wheat products, and not possibly related to safety.

Therefore, the present work mainly aimed to:

(a) Identify the main fungal species infecting kernel wheat samples showing black point symptoms, collected in Italy;

(b) Detect the presence of $\mathrm{AOH}$ in wheat kernels in the field;

(c) Study the genetic variability of the Alternaria species isolated, by sequencing the genes coding for allergen alt a1 (alt-a1), glyceraldeyde-3-phosphate dehydrogenase ( $\mathrm{gpd}$ ) and translation elongation factor 1- $\alpha$ (tef), by following a multi-locus gene sequence approach;

(d) Analyze the mycotoxin profile of selected strains of the Alternaria species identified.

\section{Results}

\subsection{Black Point Disease Symptoms on Wheat Samples}

At harvest, black point disease symptoms were evaluated on wheat plants, in both Bologna and Modena fields, according to an empirical scale with ten classes of severity $(0=$ absence of infections, $9=$ extensive symptoms of infection). Data on black point symptoms are reported in Tables 1 and 2.

Table 1. Blackpoint symptoms assessed in Bologna experimental field, Alternaria incidence of infected kernels and alternariol contamination on durum wheat genotypes.

\begin{tabular}{|c|c|c|c|c|c|c|c|}
\hline \multirow[b]{2}{*}{$\begin{array}{l}\text { Sample } \\
\text { Code }\end{array}$} & \multirow[b]{2}{*}{ Genotype } & \multicolumn{3}{|c|}{ Treated with Fungicides * } & \multicolumn{3}{|c|}{ Untreated } \\
\hline & & $\begin{array}{l}\text { Blackpoint } \\
\text { Symptoms } \\
\text { (0-9 Scale) }\end{array}$ & $\begin{array}{c}\text { Alternaria Incidence } \\
\text { of Infected Kernels } \\
(\%)\end{array}$ & $\begin{array}{l}\text { Alternariol } \\
\left(\mu \mathrm{g} \mathrm{Kg}{ }^{-1}\right)\end{array}$ & $\begin{array}{l}\text { Blackpoint } \\
\text { Symptoms } \\
\text { (0-9 Scale) }\end{array}$ & $\begin{array}{c}\text { Alternaria Incidence } \\
\text { of Infected Kernels } \\
(\%)\end{array}$ & $\begin{array}{c}\text { Alternariol } \\
\left(\mu \mathrm{g} \mathrm{Kg}{ }^{-1}\right)\end{array}$ \\
\hline G1 & D04802 & 4.0 & 5 & 34 & 5.0 & 0 & 87 \\
\hline G2 & D05422 & 2.5 & 7 & 72 & 4.5 & 12 & 148 \\
\hline G3 & 508Gd05/101 & 1.0 & 6 & 24 & 4.0 & 12 & 101 \\
\hline G6 & D07422 & 1.0 & 2 & 47 & 3.0 & 4 & 88 \\
\hline G7 & $909 \mathrm{gd} 08 / 20 \mathrm{~B}$ & 0.5 & 6 & 44 & 2.0 & 11 & 109 \\
\hline G8 & $909 g d 08 / 77$ & 2.5 & 5 & 79 & 6.0 & 13 & $\mathrm{Nd}$ \\
\hline G9 & $909 \mathrm{gd} 08 / 94 \mathrm{~A}$ & 6.0 & 5 & $\mathrm{Nd}$ & 8.0 & 16 & 124 \\
\hline G10 & $905 \mathrm{gd} 09 / 37$ & 2.0 & 15 & 55 & 4.0 & 9 & 115 \\
\hline G11 & $505 \mathrm{gd} 09 / 131 \mathrm{~A}$ & 1.5 & 12 & 51 & 3.5 & 8 & - \\
\hline G16 & $906 \mathrm{gd} 10 / 21 \mathrm{~B}$ & 4.0 & 10 & 36 & 6.0 & 8 & 97 \\
\hline G17 & $906 \mathrm{gd} 10 / 40 \mathrm{~T}$ & 0.0 & 5 & 27 & 1.5 & 8 & 88 \\
\hline G18 & $906 \mathrm{gd} 10 / 40 \mathrm{P}$ & 0.5 & 11 & 85 & 1.0 & 6 & 98 \\
\hline G19 & $906 \mathrm{gd} 10 / 72 \mathrm{~T}$ & 1.5 & 0 & 39 & 3.5 & 9 & 106 \\
\hline G20 & $906 \mathrm{gd} 10 / 72 \mathrm{P}$ & 1.5 & 8 & 40 & 3.0 & 3 & 89 \\
\hline G21 & $906 \mathrm{gd} 010 / 88 \mathrm{~A}$ & 1.0 & 0 & 43 & 1.5 & 5 & 77 \\
\hline $\mathrm{G} 22$ & $906 \mathrm{gd} 10 / 88 \mathrm{~B}$ & 0.5 & 5 & 26 & 3.0 & 8 & 40 \\
\hline $\mathrm{G} 23$ & $906 \mathrm{gd} 10 / 118 \mathrm{~T}$ & 0.5 & 3 & $\mathrm{Nd}$ & 1.5 & 12 & 93 \\
\hline G24 & $906 \mathrm{gd} 10 / 118 \mathrm{P}$ & 1.5 & 1 & 28 & 4.0 & 16 & 93 \\
\hline
\end{tabular}


Table 1. Cont.

\begin{tabular}{|c|c|c|c|c|c|c|c|}
\hline \multirow[b]{2}{*}{$\begin{array}{c}\text { Sample } \\
\text { Code }\end{array}$} & \multirow[b]{2}{*}{ Genotype } & \multicolumn{3}{|c|}{ Treated with Fungicides * } & \multicolumn{3}{|c|}{ Untreated } \\
\hline & & $\begin{array}{l}\text { Blackpoint } \\
\text { Symptoms } \\
\text { (0-9 Scale) }\end{array}$ & $\begin{array}{c}\text { Alternaria Incidence } \\
\text { of Infected Kernels } \\
(\%)\end{array}$ & $\begin{array}{c}\text { Alternariol } \\
\left(\mu \mathrm{g} \mathrm{Kg} \mathrm{g}^{-1}\right)\end{array}$ & $\begin{array}{l}\text { Blackpoint } \\
\text { Symptoms } \\
\text { (0-9 Scale) }\end{array}$ & $\begin{array}{c}\text { Alternaria Incidence } \\
\text { of Infected Kernels } \\
(\%)\end{array}$ & $\begin{array}{c}\text { Alternariol } \\
\left.(\mu \mathrm{g} \mathrm{Kg})^{-1}\right)\end{array}$ \\
\hline \multicolumn{2}{|c|}{ Min value } & 0 & 0 & 0 & 0.5 & 0 & 0 \\
\hline \multicolumn{2}{|c|}{ Max value } & 6 & 26 & 85 & 8 & 16 & 148 \\
\hline \multicolumn{2}{|c|}{ Average } & 1.9 & 7.4 & 39.1 & 3.5 & 9.1 & 84.2 \\
\hline \multicolumn{2}{|c|}{ Standard Deviation } & 1.5 & 5.8 & 22.3 & 1.8 & 4.1 & 34.3 \\
\hline G25 & CLAUDIO & 1.0 & 6 & 42 & 6.0 & 9 & 97 \\
\hline G26 & IRIDE & 3.0 & 9 & 91 & 6.0 & 6 & $\mathrm{Nd}$ \\
\hline G27 & LIBERDUR & 1.0 & 20 & 44 & 2.0 & 11 & 77 \\
\hline G28 & $\begin{array}{l}\text { MARCO } \\
\text { AURELIO }\end{array}$ & 3.0 & 2 & 66 & 5.0 & 21 & 110 \\
\hline G29 & MIRADOUX & 1.0 & 7 & 87 & 2.0 & 10 & 87 \\
\hline G30 & SARAGOLLA & 2.5 & 9 & 92 & 4.0 & 17 & 110 \\
\hline
\end{tabular}

* First treatment with trifloxystrobin+cyproconazole $\left(0.5 \mathrm{Lha}^{-1}\right)$ during doffing time and a second treatment with prothioconazole $\left(0.8 \mathrm{Lha}^{-1}\right)$ during earing time.

Table 2. Black point symptoms assessed in Modena experimental field, Alternaria incidence of infected kernels and alternariol contamination on durum wheat genotypes.

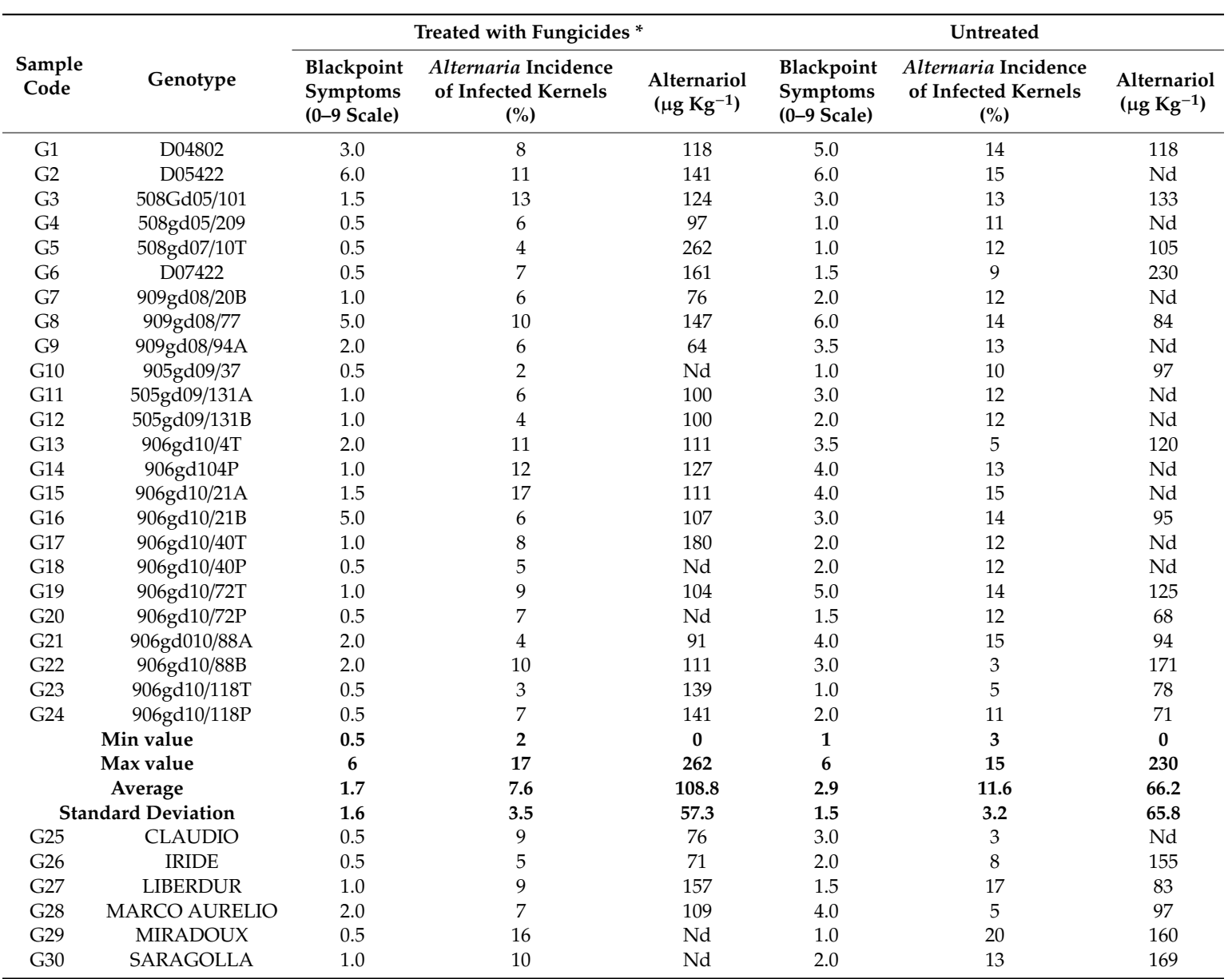

* First treatment with trifloxystrobin+cyproconazole $\left(0.5 \mathrm{Lha}^{-1}\right)$ during doffing time and a second treatment with prothioconazole $\left(0.8 \mathrm{Lha}^{-1}\right)$ during earing time.

In the Bologna field, with the exception of the G17 genotype, exposed to fungicide treatment, all theses showed black point symptoms. Black point symptoms were more severe on plants not exposed to fungicide treatment. Indeed, comparing the same genotypes, treated or untreated with fungicide, black point symptoms were more evident on untreated plants (Table 1). On untreated plants, symptoms ranged between 0.5 (G5 genotype) and 8 (G9 genotype), with a mean value of 3.5. Treated 
plants showed symptoms ranging between 0 (G17) and 4 (G1 and G16 genotypes), with a mean value of 1.9. Data on commercial varieties are summarized also in Table 1 and confirmed that fungicide treatment reduced drastically black point symptoms.

Data from the Modena field are summarized in Table 2 and confirmed that the highest black point symptoms were recorded in untreated plots, although they were lower than in the Bologna field.

\subsection{Alternariol Contamination of Wheat Samples}

Data on contamination of kernels by $\mathrm{AOH}$ are reported in Table 1. In the Bologna field, $88 \%$ of the samples were contaminated by AOH. Three samples exposed to fungicide spraying (G5, G9, G23) and four untreated samples (G4, G8, G11, Iride) were not contaminated from AOH. In the plots exposed to fungicide treatment the contamination values ranged from $24 \mu \mathrm{g} \mathrm{kg}^{-1}$ (G3) to $92 \mu \mathrm{g} \mathrm{kg}^{-1}$ (Saragolla), with a mean value of $39 \mathrm{\mu g} \mathrm{kg}^{-1}$. In the untreated samples the contamination values ranged between 40 (G22) and 148 (G2) $\mu \mathrm{g} \mathrm{kg}^{-1}$, with a mean value of $84 \mu \mathrm{g} \mathrm{kg}^{-1}$. With the exception of the samples G4, G8 and Iride, in which chemical treatment did not influence AOH contamination, the treated plots showed a lower contamination of $\mathrm{AOH}$ than untreated plots (Table 1).

In the Modena field, $\mathrm{AOH}$ contamination was higher than in the Bologna field. In treated plots the $\mathrm{AOH}$ contamination ranged between 64 (G9) and 262 (G5) $\mu \mathrm{g} \mathrm{kg}{ }^{-1}$, with mean value of $109 \mu \mathrm{g} \mathrm{kg}^{-1}$; in an untreated plot the level of AOH contamination ranged between 68 (G20) and $230(\mathrm{G} 6) \mu \mathrm{g} \mathrm{kg}^{-1}$, with a mean value $66 \mu \mathrm{g} \mathrm{kg}^{-1}$. In the Modena trial, a strict correlation between $\mathrm{AOH}$ contamination and chemical treatment was not observed. In 17 out of 30 untreated samples the $\mathrm{AOH}$ contamination was lower than the same genotypes or commercial cultivar spayed with chemicals (Table 2).

\subsection{Detection of Fungal Infection}

Fungal infection was detected in all wheat samples, with values ranging between $21 \%$ and $83 \%$ in the Bologna field and between $71 \%$ and $98 \%$ in the Modena field (data not shown). Un-treated samples were slightly more infected than treated samples. Particular attention was focused on Alternaria and Fusarium genera. Among the fungal colonies morphologically identified as belonging to Alternaria and Fusarium genera, 382 monoconidial representative isolates of Alternaria spp. and 177 of Fusarium spp. were recovered from the infected kernels.

Infection by Alternaria species occurred in 118 out of 120 wheat samples, ranging from $1 \%$ to $26 \%$ in the Bologna field (Table 1), with mean value of $8 \%$ and $10 \%$ for treated and untreated theses, respectively; the incidence of infected kernels ranging between $2 \%$ and $20 \%$ were detected in Modena field (Table 2), with mean value of $8 \%$ and $12 \%$ in treated and untreated theses, respectively. The infection rate at the Alternaria species level was also evaluated.

In 88 out of 120 wheat samples, strains belonging to the Fusarium genus were also detected; however, Fusarium spp incidence of infected kernels was very low, up to $7 \%$, with mean values in treated and untreated plots of $1.2 \%$ and $2.3 \%$, respectively (data not shown).

Total fungal infection and therefore Alternaria infection rate was lower in treated than untreated theses, according with the black-point symptoms assessed in fields during the field inspections (Table 1; Table 2). However, between the symptoms of black point disease and average of Alternaria species infection, a strict correlation was not observed.

\subsection{Morphological Characterization}

All the 382 mono-conidial strains, representative of the whole population found on the 120 samples, grew very quickly on potato dextrose agar (PDA) and potato-carrot agar (PCA), usually covering the whole surface of the Petri plates, and showing abundant sporulation. Conidia and conidiophore branch morphologies were used to identify the Alternaria species, according to Simmons [21]. Almost all 382 isolates were related to four morphospecies: A. alternata, A. tenuissima, A. arborescens, A. infectoria. In detail, 125 isolates were identified as A. alternata, 152 were identified as $A$. tenuissima, 72 were identified as $A$. arborescens and 33 were identified as $A$. infectoria. 


\subsection{PCR Amplification and Phylogenetic Analysis}

All the 92 selected Alternaria strains gave PCR products of the expected size for the alt-a1 and tef genes tested. In all Alternaria strains, morphologically identified as A. infectoria, a detection of $55 \mathrm{nt}$ in the first part of the gpd region sequence amplified, was observed.

Fragment of tef gene showed a lower variability with few polymorphic regions. The gene showing the higher degree of variability was alt-a1. In particular, the higher variability was observed in all the alt-a1 sequences where a $6 \mathrm{nt}$ deletion in A. infectoria group compared to A. alternata, A. tenuissima and $A$. arborescens groups was observed. Moreover, the final part of the resulting fragment was highly polymorphic.

The analysis of the combined sequences of the three genes resulting in a Maximum Parsimony tree is shown in Figure 1. The phylogenetic tree, obtained with Mega5 allowed us to define two well-separated clades, corresponding to Alternaria section (clade A) and Infectoriae section (clade B). Clade B grouped all the Alternaria reference strains belonging to Infectoriae section and eight out of 92 strains tested (Figure 1). A high variability was observed; however, seven out of eight strains of this clade and A. ventricosa reference strain, formed a well-supported (99 bootstrap value) group, that differed from the A. triticina reference strain. Among Alternaria strains grouped in this clade, strain ITEM17335 was highly similar to A. rosae E.G.S. 41-130 reference strain and was well separated by Infectoriae section.

A big group of 84 strains formed the Clade A, supported by a bootstrap value of 93 . Within this clade, three sub-clades were defined; sub-clade A1 included 30 field strains and $A$. arborescens and A. cerealis reference strains. Forty-two strains were (morphologically identified as A. alternata and A. tenuissima species) grouped with A. alternata (E.G.S. 34.016), A. tenuissima (E.G.S. 34.015) reference strains, A. alternata BMP0270, A. limoniasperae BMP2335 and A. turkisafria BMP3436 (sub-clade A2); sub-clade A3 included 12 field strains and showed 100\% homology with A. mali BMP3064.

In sub-clade A2, strains shared a very high level of homology and therefore it was not possible to distinguish between A. alternata and A. tenuissima species, in terms of morphological definitions. On the contrary, a great variability was observed in sub-clade $\mathrm{A} 1$ which grouped $A$. arborescens reference stains and 30 of the our Alternaria strains (Figure 1). 


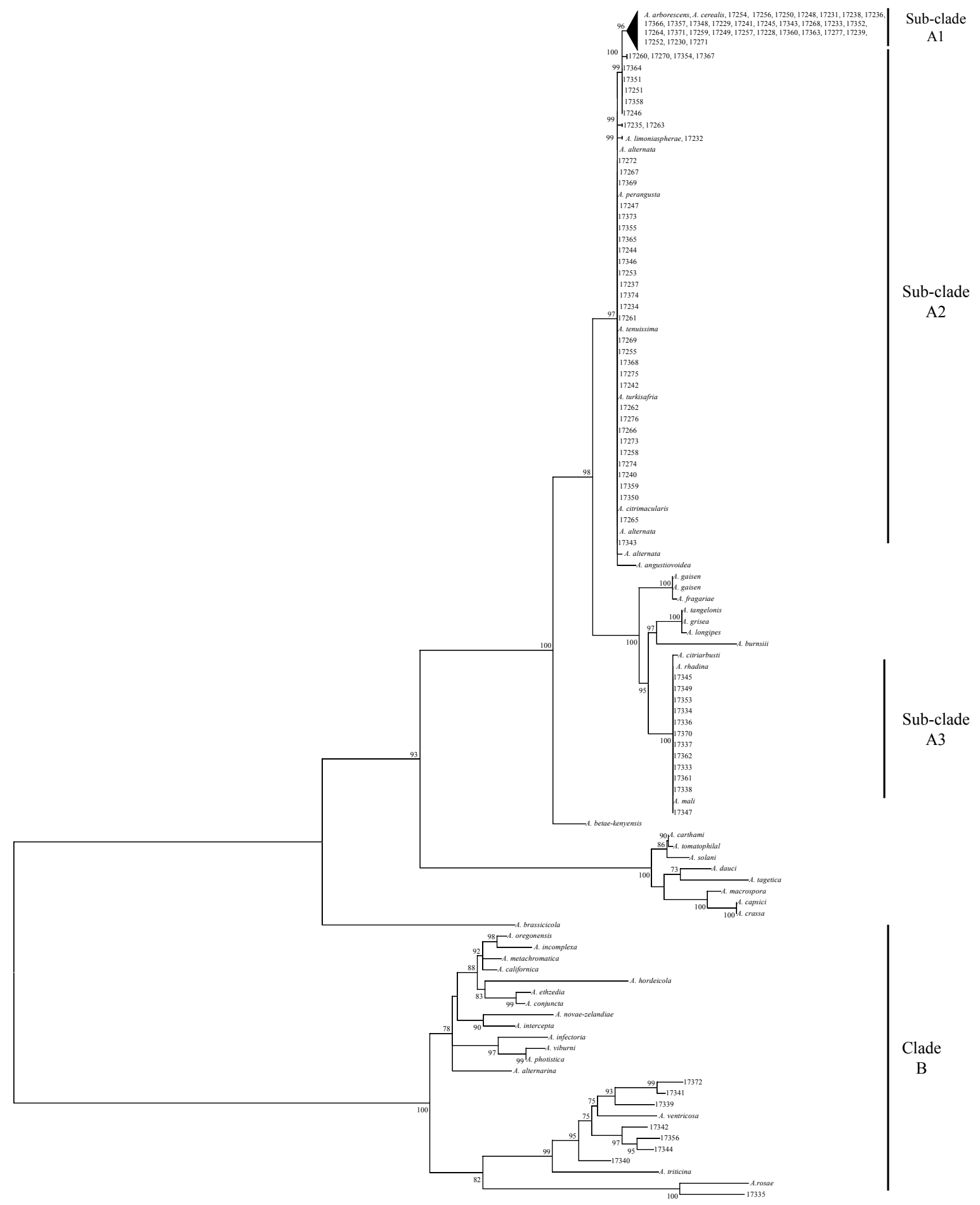

Figure 1. Phylogenetic tree generated by maximum parsimony method (bootstrap 1000 replicates) of combined allergen alt a1 (alt-a1), glyceraldeyde-3-phosphate dehydrogenase ( $g p d$ ), and translation elongation factor 1- $\alpha$ (tef) gene sequences of 92 Alternaria strains.

\subsection{Design of Infectoriae Section Specific PCR Primers}

Based on the deletion of 55 nucleotides observed in the first part of the obtained gpd sequences of Alternaria strains belonging to Infectoriae section, specific primers pair was designed by using Primer3 software [34]. In detail, forward primer (Ainf29Fw-5'CGTCTTCCGCAATGCTATCG3') overlapped the deleted region (Figure 2) and reverse primer (Ainf277Rev—5' ACCTTGATCTCGCCCTTGAA3') 
was designed in a region common to all Alternaria strains. PCR conditions were optimized to amplify the specific fragment of $249 \mathrm{nt}$, as follows: an initial stage at $95{ }^{\circ} \mathrm{C}$ for 2 minutes; 30 cycles each consisting of a step at $95^{\circ} \mathrm{C}$ for $30 \mathrm{sec}, 58^{\circ} \mathrm{C}$ for $30 \mathrm{sec}$ and $72{ }^{\circ} \mathrm{C}$ for $30 \mathrm{sec}$, and a final stage at $72{ }^{\circ} \mathrm{C}$ for 7 minutes.

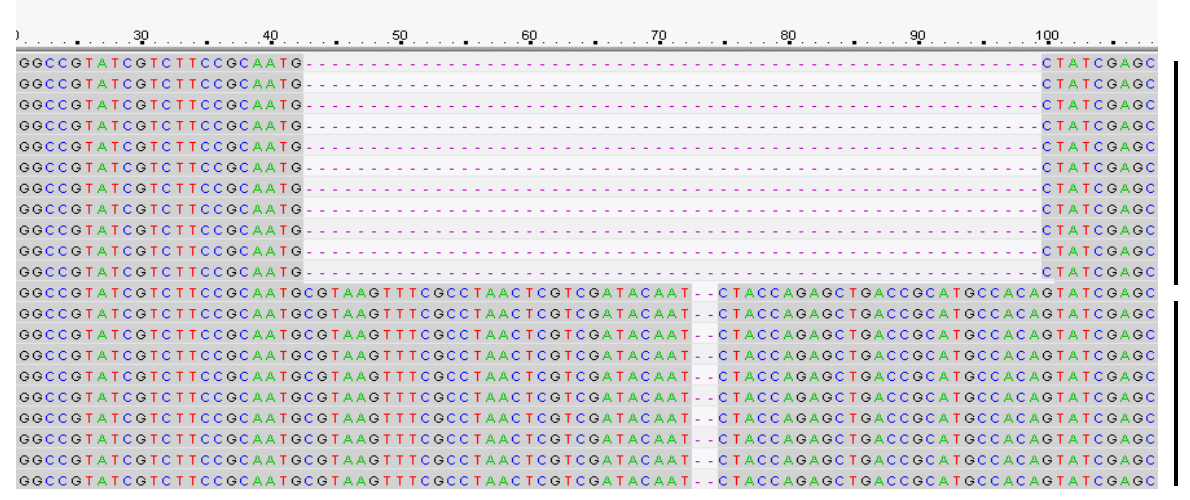

\section{Infectoriae \\ Section}

Alternaria

Section

Figure 2. Deletion of $55 \mathrm{nt}$ in gpd sequence of Alternaria strains belonging to Infectoriae section. Ainf29Fw primer (5'-CGTCTTCCGCAATGCTATCG3-3'), designed on deletion site, was able to discriminate among Alternaria and Infectoriae Sections.

\subsection{Mycotoxins Production of Alternaria Strains}

Mycotoxins, with the exception of the A. infectoria ITEM 17344 strain, were detected in all rice cultures, as reported in Table 3 . In all the strains, $\mathrm{AOH}$ and $\mathrm{AME}$ production was very variable, ranging between 1 and $8064 \mathrm{mg} \mathrm{kg}^{-1}$ and between 1 and 14,341 $\mathrm{mg} \mathrm{kg}^{-1}$ for AOH and AME, respectively. In general, as shown in Table 3, even considering the species identification obtained by phylogenetic analysis, mycotoxin production of both $\mathrm{AOH}$ and $\mathrm{AME}$ was very variable. Mean values of $\mathrm{AOH}$ and AME were also reported in Table 3 for each phylogenetic clade or sub-clade. Alternariol and AME production of strains belonging to sub-clade A2, showed mean values of 774 and $2099 \mathrm{mg} \mathrm{kg}^{-1}$, respectively. Similar mean values were reported for sub-clade A1 (884 and $1449 \mathrm{mg} \mathrm{kg}^{-1}$ ) and sub-clade A3 (651 and $1773 \mathrm{mg} \mathrm{kg}^{-1}$ ).

Only the strains belonging to clade $\mathrm{B}$, assigned to A. infectoria species group, were low or no producers of toxins. The quantity of mycotoxins, with the exception of the strain ITEM17356 (AOH 223; AME $151 \mathrm{mg} \mathrm{kg}^{-1}$ ). ranged between 0 and $68 \mathrm{mg} \mathrm{kg}^{-1}$ (mean value 16) for $\mathrm{AOH}$ and between 1 and $64 \mathrm{mg} \mathrm{kg}^{-1}$ (mean value 15) for AME.

With regard to ALT production, only 2 out of 73 strains tested, A. arborescens ITEM 17230 $\left(2.5 \mathrm{mg} \mathrm{kg}^{-1}\right)$ and A. alternata ITEM $17244\left(25 \mathrm{mg} \mathrm{kg}^{-1}\right)$, were able to synthetize low content of this mycotoxin.

Tenuazonic acid was detected in 50 out of 73 stains with values ranging between $23 \mathrm{mg} \mathrm{kg}^{-1}$ (A. infectoria ITEM 17372 strain) and $3684 \mathrm{mg} \mathrm{kg}^{-1}$ (A. mali ITEM17349 strain). In particular, the highest TA amount was detected among the strains grouped in the sub-clade A3. All the strains belonging to A3 sub-clade showed a great capability to produce the TA with values ranging between $736 \mathrm{mg} \mathrm{kg}^{-1}$ and $3684 \mathrm{mg} \mathrm{kg}^{-1}$ (mean value $1733 \mathrm{mg} \mathrm{kg}^{-1}$ ). Among the strains identified as A. alternaria and A tenuissima, 8 strains were not able to produce TA and 27 out of 35 strains were high TA producers, with values ranging between $183 \mathrm{mg} \mathrm{kg}^{-1}$ and $2388 \mathrm{mg} \mathrm{kg}^{-1}$ (mean value $723 \mathrm{mg} \mathrm{kg}^{-1}$ ). Alternaria arborescens strains produced TA with values ranging between 157 and $3043 \mathrm{mg} \mathrm{kg}^{-1}$ (mean value of $730 \mathrm{mg} \mathrm{kg}^{-1}$ ); however 9 out of 22 strains were not a TA producer. With regard to strains grouped with A. infectoria reference strain, except the strain ITEM 17372 (TA content of $23 \mathrm{mg} \mathrm{kg}^{-1}$ ), all strains were not producers. 
Table 3. Alternariol (AOH), alternariol methyl ether (AME), altenuene (ALT) and tenuazonic acid (TE) content, produced by Alternaria strains.

\begin{tabular}{|c|c|c|c|c|c|c|c|c|c|c|c|c|c|c|}
\hline \multirow{2}{*}{$\begin{array}{l}\text { Strain } \\
\text { (ITEM) }\end{array}$} & \multicolumn{4}{|c|}{$\mathrm{mg} \mathrm{kg}^{-1}$} & \multirow{2}{*}{$\begin{array}{l}\text { Strain } \\
\text { (ITEM) }\end{array}$} & \multicolumn{4}{|c|}{$\mathrm{mg} \mathrm{kg}^{-1}$} & \multirow{2}{*}{$\begin{array}{l}\text { Strain } \\
\text { (ITEM) }\end{array}$} & \multicolumn{4}{|c|}{$\mathrm{mg} \mathrm{kg}^{-1}$} \\
\hline & $\mathrm{AOH}$ & AME & ALT & TA & & $\mathrm{AOH}$ & AME & ALT & TA & & $\mathrm{AOH}$ & AME & ALT & TA \\
\hline $17235^{\mathrm{A} 2}$ & 67 & 182 & - & - & $17272^{\mathrm{A} 2}$ & 38 & 310 & $\mathrm{Nd}$ & 1030 & $17348^{\mathrm{A} 1}$ & 127 & 501 & $\mathrm{Nd}$ & 1775 \\
\hline $17237^{\mathrm{A} 2}$ & 815 & 2618 & $\mathrm{Nd}$ & 603 & $17274^{\mathrm{A} 2}$ & 46 & 185 & $\mathrm{Nd}$ & 965 & $17271^{\mathrm{A} 1}$ & 448 & 2703 & - & - \\
\hline 17242 A2 & 1070 & 2557 & $\mathrm{Nd}$ & 1022 & $17276^{\mathrm{A} 2}$ & 26 & 353 & $\mathrm{Nd}$ & 977 & $17277^{\mathrm{A} 1}$ & 1085 & 2113 & $\mathrm{Nd}$ & 311 \\
\hline $17243^{\text {A2 }}$ & 251 & 2167 & $\mathrm{Nd}$ & 306 & $17350^{\text {A2 }}$ & 65 & 371 & $\mathrm{Nd}$ & 476 & 17352 A1 & 1002 & 1306 & $\mathrm{Nd}$ & 157 \\
\hline $17244^{\mathrm{A} 2}$ & 100 & 1000 & 25 & $\mathrm{Nd}$ & $17351^{\mathrm{A} 2}$ & 69 & 798 & $\mathrm{Nd}$ & 934 & $17357^{\mathrm{A} 1}$ & 752 & 3849 & $\mathrm{Nd}$ & 2725 \\
\hline $17247^{\text {A2 }}$ & 1682 & 2349 & - & - & $17354^{\text {A2 }}$ & 85 & 9 & $\mathrm{Nd}$ & 1596 & $17360^{\mathrm{A} 1}$ & 1 & 5 & - & - \\
\hline $17258^{\text {A2 }}$ & 46 & 65 & - & 575 & $17355^{\text {A2 }}$ & 372 & 2239 & - & - & $17363^{\mathrm{A} 1}$ & 145 & 14 & $\mathrm{Nd}$ & $\mathrm{Nd}$ \\
\hline $17260^{\mathrm{A} 2}$ & 1169 & 7965 & $\mathrm{Nd}$ & 755 & $17358^{\text {A2 }}$ & 138 & 369 & $\mathrm{Nd}$ & 572 & $17366^{\mathrm{A} 1}$ & 22 & 30 & $\mathrm{Nd}$ & $\mathrm{Nd}$ \\
\hline $17269^{\text {A2 }}$ & 378 & 129 & $\mathrm{Nd}$ & $\mathrm{Nd}$ & $17364^{\text {A2 }}$ & 872 & 2396 & - & - & $17371^{\text {A1 }}$ & 1512 & 2035 & $\mathrm{Nd}$ & $\mathrm{Nd}$ \\
\hline $17270^{\mathrm{A} 2}$ & 872 & 50 & $\mathrm{Nd}$ & $\mathrm{Nd}$ & $17374^{\mathrm{A} 2}$ & 992 & 3357 & $\mathrm{Nd}$ & 642 & Average A1 & 884 & 1449 & - & 730 \\
\hline $17273^{\mathrm{A} 2}$ & 1822 & 5603 & $\mathrm{Nd}$ & 1654 & Average A2 & 774 & 2099 & - & 723 & $17333^{\mathrm{A} 3}$ & 1633 & 1934 & - & - \\
\hline $17275^{\mathrm{A} 2}$ & 7372 & 13,156 & $\mathrm{Nd}$ & 1009 & $17228^{\mathrm{A} 1}$ & 651 & 548 & $\mathrm{Nd}$ & $\mathrm{Nd}$ & $17334^{\mathrm{A} 3}$ & 60 & 91 & - & - \\
\hline $17346^{\text {A2 }}$ & 3152 & 7143 & $\mathrm{Nd}$ & 938 & $17229^{\text {A1 }}$ & 23 & 33 & - & - & $17336^{\text {A3 }}$ & 62 & 620 & $\mathrm{Nd}$ & 2143 \\
\hline $17359^{\text {A2 }}$ & 11 & 5 & - & - & $17230^{\mathrm{A} 1}$ & 4176 & 4213 & 2.5 & 822 & $17337^{\mathrm{A} 3}$ & 415 & 2866 & - & - \\
\hline $17365^{\mathrm{A} 2}$ & 3581 & 14,341 & $\mathrm{Nd}$ & 1656 & $17231^{\mathrm{A} 1}$ & 1283 & 2567 & $\mathrm{Nd}$ & $\mathrm{Nd}$ & $17338^{\mathrm{A} 3}$ & 1781 & 2763 & $\mathrm{Nd}$ & 1084 \\
\hline $17367^{\mathrm{A} 2}$ & 62 & 39 & $\mathrm{Nd}$ & $\mathrm{Nd}$ & $17233^{\mathrm{A} 1}$ & 22 & 163 & $\mathrm{Nd}$ & 3043 & $17345^{\mathrm{A} 3}$ & 28 & 385 & $\mathrm{Nd}$ & 2485 \\
\hline $17368^{\mathrm{A} 2}$ & 40 & 374 & $\mathrm{Nd}$ & 377 & $17236^{\mathrm{A} 1}$ & 1283 & 1612 & - & - & $17347^{\mathrm{A} 3}$ & 213 & 288 & $\mathrm{Nd}$ & 1767 \\
\hline $17369^{\text {A2 }}$ & 57 & 230 & - & - & $17238^{\mathrm{A} 1}$ & 925 & 1833 & - & - & $17349^{\mathrm{A} 3}$ & 73 & 1039 & $\mathrm{Nd}$ & 3684 \\
\hline $17373^{\mathrm{A} 2}$ & 245 & 823 & $\mathrm{Nd}$ & 985 & $17239^{\mathrm{A} 1}$ & 89 & 10 & $\mathrm{Nd}$ & $\mathrm{Nd}$ & $17353^{A 3}$ & 451 & 287 & $\mathrm{Nd}$ & 773 \\
\hline $17232^{\mathrm{A} 2}$ & 1962 & 4485 & $\mathrm{Nd}$ & $\mathrm{Nd}$ & $17241^{\mathrm{A} 1}$ & 154 & 29 & $\mathrm{Nd}$ & $\mathrm{Nd}$ & $17361^{\mathrm{A} 3}$ & 23 & 16 & $\mathrm{Nd}$ & 736 \\
\hline $17234^{\text {A2 }}$ & 1296 & 2775 & $\mathrm{Nd}$ & $\mathrm{Nd}$ & $17245^{\mathrm{A} 1}$ & 8064 & 8597 & - & - & $17362^{\mathrm{A} 3}$ & 636 & 2261 & $\mathrm{Nd}$ & 2111 \\
\hline $17246^{\text {A2 }}$ & 842 & 1257 & $\mathrm{Nd}$ & 914 & $17248^{\mathrm{A} 1}$ & 1309 & 1067 & $\mathrm{Nd}$ & 1417 & $17370^{\mathrm{A} 3}$ & 2434 & 8730 & $\mathrm{Nd}$ & 816 \\
\hline $17251^{\mathrm{A} 2}$ & 34 & 30 & $\mathrm{Nd}$ & 710 & $17249^{\text {A1 }}$ & 948 & 2606 & $\mathrm{Nd}$ & 920 & Average A3 & 651 & 1773 & & 1733 \\
\hline $17253^{\mathrm{A} 2}$ & 32 & 127 & $\mathrm{Nd}$ & 2059 & $17250^{\mathrm{A} 1}$ & 531 & 2437 & $\mathrm{Nd}$ & 750 & $17335^{B}$ & 68 & 4 & $\mathrm{Nd}$ & $\mathrm{Nd}$ \\
\hline $17255^{\mathrm{A} 2}$ & 162 & 605 & $\mathrm{Nd}$ & 621 & $17252^{\mathrm{A} 1}$ & 611 & 787 & - & - & $17339^{\text {B }}$ & 25 & 64 & $\mathrm{Nd}$ & $\mathrm{Nd}$ \\
\hline $17261^{\mathrm{A} 2}$ & 221 & 2174 & - & - & $17254^{\mathrm{A} 1}$ & 50 & 53 & $\mathrm{Nd}$ & $\mathrm{Nd}$ & $17340^{\text {B }}$ & 12 & 19 & $\mathrm{Nd}$ & $\mathrm{Nd}$ \\
\hline 17262 A2 & 25 & 6 & $\mathrm{Nd}$ & 901 & $17256^{\mathrm{A} 1}$ & 505 & 1045 & $\mathrm{Nd}$ & 953 & $17341^{B}$ & 8 & 11 & - & - \\
\hline $17263^{\mathrm{A} 2}$ & $\mathrm{Nd}$ & 49 & $\mathrm{Nd}$ & 183 & $17257^{\mathrm{A} 1}$ & $\mathrm{Nd}$ & $\mathrm{Nd}$ & $\mathrm{Nd}$ & 605 & $17342^{\text {В }}$ & 5 & 4 & $\mathrm{Nd}$ & $\mathrm{Nd}$ \\
\hline $17240^{\mathrm{A} 2}$ & 316 & 166 & $\mathrm{Nd}$ & $\mathrm{Nd}$ & $17259^{\mathrm{A} 1}$ & 240 & 87 & $\mathrm{Nd}$ & 680 & $17344^{\text {B }}$ & $\mathrm{Nd}$ & $\mathrm{Nd}$ & $\mathrm{Nd}$ & $\mathrm{Nd}$ \\
\hline $17265^{\mathrm{A} 2}$ & 44 & 357 & $\mathrm{Nd}$ & 2388 & $17264^{\mathrm{A} 1}$ & 112 & 152 & $\mathrm{Nd}$ & 1911 & $17356^{\text {B }}$ & 223 & 151 & $\mathrm{Nd}$ & $\mathrm{Nd}$ \\
\hline $17266^{\mathrm{A} 2}$ & 420 & 2178 & $\mathrm{Nd}$ & 463 & $17268^{\mathrm{A} 1}$ & 300 & 635 & $\mathrm{Nd}$ & $\mathrm{Nd}$ & $17372^{\text {В }}$ & 0 & 1 & $\mathrm{Nd}$ & 23 \\
\hline $17267^{\mathrm{A} 2}$ & 880 & 2765 & $\mathrm{Nd}$ & $\mathrm{Nd}$ & $17343^{\mathrm{A} 1}$ & 143 & 2442 & - & - & Average ${ }^{B}$ & 43 & 32 & - & - \\
\hline
\end{tabular}

A2 = A. alternata/A. tenuissma (sub-clade A2); A1 = A. arborescens (sub-clade A1); A3 = A. mali (sub-clade A3); B = A. infectoria (clade B); Nd = Not detected. 


\section{Discussion}

In the present study, $\mathrm{AOH}$ contamination was detected on $82 \%$ of wheat samples with values ranging between 24 and $262 \mu \mathrm{g} \mathrm{Kg}{ }^{-1}$. These data show that the occurrence of $\mathrm{AOH}$ in kernels collected in the field was extended and maybe it was related to the colonization process of the Alternaria species, as shown by Wenderoth et al. [33] in apple, citrus and tomato for Alternaria alternata. However, if $\mathrm{AOH}$ is a virulence and colonization factor for Alternaria infection on wheat, this needs to be confirmed. Moreover, the toxigenic risk has to be taken in account, since the $\mathrm{AOH}$ contamination of samples was high.

Fungicide treatments showed that Alternaria was less influenced by the fungicide application compared to total fungal infection. The reduction of fungicide efficacy against Alternaria species was previously reported by Avenot et al. [35] as a consequence of resistant strains occurring in the field. Further studies could be useful to explain the different response of fungicides against the main fungal species recovered on wheat.

Alternaria incidence of infected kernels, was rather lower than expected, in both experimental fields, if compared to the symptoms of black point disease. Even if black point symptoms, detected in the field, ranged from low to moderate visible infection (mean value of severity scale $=2.5$ ), a low correlation was observed between disease symptoms and Alternaria infection.

This divergent result could be explained by the implication of other fungal species in the black point disease, or by abiotic damages associated with the dark brown discolouration of the wheat kernels.

The lack of congruence in Alternaria infection, disease symptoms and mycotoxin accumulation in wheat samples could be also linked to a different capability of the species to colonize plant tissue or to produce mycotoxins in field conditions. In addition, plant defence mechanisms, host and different pedo-climatic conditions could interfere in fungal colonization. Indeed, mycotoxin production by Alternaria strains revealed that almost all Alternaria strains tested showed a great capability to produce $\mathrm{AOH}$ and $\mathrm{AME}$ when grown in vivo on autoclaved rice, in which no mechanical barriers occur and many of the grain defences, that are thermos-labile, have been suppressed [36]. Although small-spored Alternaria species are of high economic relevance, they are poorly investigated among pathogenic fungi, mainly due to the difficulties of differentiating between species [37]. The morphological identification of Alternaria population carried out in the present study, performed according to Simmons [21], lead to assign all the strains to four main Alternaria species: A. tenuissima, A. alternata, A. arborescens and $A$. infectoria. These species are widely reported as the most occurring Alternaria species on wheat $[8,12,14]$. However, for a more accurate identification, we carried out a poly-phasic approach, using also molecular and chemical techniques [38,39].

In recent years, molecular studies revealed multiple non-monophyletic species within Alternaria complex and Alternaria species clades which do not always correlate to a species-group based upon morphological characteristics [7,14,40-44].

Through our phylogenetic analyses A. alternata and A. tenuissima morpho-species were not distinguishable. This result is in accordance with several studies aimed to identify Alternaria species by using different molecular tools, such as AFLP [45] and RAPD-PCR [46]. A wide investigation on the Alternaria genus by phylogenetic analysis was carried out by Woudenberg et al. [16]. Although eleven genes sequences were used, $A$. alternata and A. tenuissima were yet not resolved, suggesting validity of the hypothesis that considers these two morpho-species as the same phylogenetic species [16]. On the other hand, in the present study, it was possible to distinguish $A$. arborescens strains from the A. alternata species group, all belonging to Alternaria section as defined by the recent taxonomic rearrangement of Alternaria genus [16]. At the same section we also assigned the group, named in this work as sub-clade A3, including strains with high homology with reference strains of A. citriarbusti, A. radhina and A. mali.

Our results indicate that population structure of Alternaria species associated with black point disease, is prevalently represented by A. tenuissima and A. alternata (about $50 \%$ of total strains tested), as observed in previous studies [7,9]. Moreover, $A$. arborescens was also identified in wheat in accordance with other recent studies in Argentina [18,47], Tunisia [48], Germany, and Russia [49]. 
Finally, in this work, a small number of A. infectoria strains were also isolated from wheat, confirming a previous report from Italy [7], and other reports from Norway, Argentina, Germany and Russia $[23,49,50]$.

Thus, Alternaria species composition on wheat is evolving, influenced by agricultural practices and environmental conditions. Moreover, great concern in the scientific community exists, because of the ability of Alternaria species to infect a huge number of field and processed wheat products and their ability to produce a range of mycotoxins, with $\mathrm{AOH}$ and AME being the most frequent and dangerous metabolites [12,51].

In our study, Alternaria strains examined showed a very variable amount of $\mathrm{AOH}$ and AME production, with mean values of about 800 and $1800 \mathrm{mg} \mathrm{kg}^{-1}$ for $\mathrm{AOH}$ and AME, respectively, except for the group (eight strains) assigned to the A. infectoria section. These strains showed very low toxin production abilities, confirming that $A$. infectoria strains are weak or no mycotoxin producers, as previously reported $[8,45,49]$. Thus, while A. alternata, A. tenuissima and A. arborescens, phylogenetically clustered in the same Alternaria section, and represent a serious risk for human heath since almost all strains produce $\mathrm{AOH}$ and AME [8], A. infectoria is not a particular threat for mycotoxin risk in wheat, due to the lack of mycotoxin production. For this reason, diagnostic tools based on the molecular detection of $A$. infectoria strains can allow a rapid evaluation of Alternaria mycotoxin risk assessment in wheat samples.

Consumption of wheat invaded by Alternaria does not necessarily imply mycotoxin presence in the grains but it indicates a potential risk for contamination. Mycotoxins of Alternaria have not yet received the same attention as mycotoxins produced by other fungal genera [49] although they are associated with many different diseases in humans, animals and plants [8,52]. However, nowadays consumers demand food and feed productions with a high qualitative standards to guarantee human and animal health. In this respect, and considering the continuously changing species composition, a future regulation of Alternaria mycotoxins could be expected, making more urgent, deeper and wider investigations on Alternaria species and related mycotoxins.

\section{Materials and Methods}

\subsection{Origin of Wheat Samples}

The 120 durum wheat samples analyzed in this work, were collected from two experimental fields, "San Lazzaro di Savena" (Bologna) and "Castelfranco Emilia" (Modena), located in the Emilia Romagna region, in Northern Italy. The susceptibility to black point disease of 24 durum wheat genotypes obtained with cross-breeding activities, was evaluated and compared with 6 commercial cultivars. In both fields, each genotype was grown in two replicates by using a randomized block design. In particular, one replicate was grown under high-input (fungicide application) and one replicate under low-input (no fungicide application) agronomic strategies. The treated plants were exposed to a first treatment with fungicide containing a mixture of Trifloxystrobin and Cyproconazole at the dose of 0.5 litre per hectare $\left(\mathrm{L} \mathrm{ha}^{-1}\right)$, at raising growth stage, and a second treatment with a formulate containing Prothioconazole, at the dose of $0.8 \mathrm{~L} \mathrm{ha}^{-1}$, at earing stage.

\subsection{Evaluation of Black Point Symptoms}

At kernels maturity stage, black point symptoms were evaluated according to an empirical scale with ten classes of severity $(0=$ absence of infections, $9=$ extensive symptoms of infection).

\subsection{Fungal Isolation and Growth Conditions}

Representative kernels of the wheat samples (100 kernels), randomly collected at harvest time, were stored at $4{ }^{\circ} \mathrm{C}$ and then tested to detect the fungal incidence of infected kernels.

After superficial disinfection in $2 \%$ sodium hypochlorite solution for $2 \mathrm{~min}$ and two washing with distilled sterilized water for $1 \mathrm{~min}, 100$ representative kernels for each sample, randomly 
collected, were plated (10 kernels/plate) on potato dextrose agar (PDA) added with $0.2 \mathrm{~g} \mathrm{~L}^{-1}$ of penthacloronitrobenzene (PCNB), $0.10 \mathrm{~g} \mathrm{~L}^{-1}$ of streptomycin sulphate salt and $0.05 \mathrm{~g} \mathrm{~L}^{-1}$ of neomycin. Incubation was performed at $25 \pm 1{ }^{\circ} \mathrm{C}$ for 5 days under an alternating light/darkness cycle of $12 \mathrm{~h}$ photoperiod.

Total fungal incidence of infected kernels, and Alternaria, Fusarium, Aspergillus and Penicillium infection was calculated for each sample. Pure cultures of representative isolates belonging to Alternaria and Fusarium species, were isolated. To obtain mono-conidial isolates, conidia were spread at low density on water agar (WA: $20 \mathrm{~g} \mathrm{~L}^{-1}$ agar Oxoid n. 3) and singly collected after germination, using a dissection microscope, on PDA. Isolates were identified on the basis of colony and conidia morphology on PDA and potato-carrot agar (PCA: infusion from $20 \mathrm{~g}$ peeled and sliced white potatoes, $20 \mathrm{~g}$ carrot kept at $60^{\circ} \mathrm{C}$ for $1 \mathrm{~h} ; 15 \mathrm{~g} \mathrm{~L}^{-1}$ agar Oxoid $\mathrm{n}$. 3), after 7 days of incubation at $25 \pm 1^{\circ} \mathrm{C}$ under an alternating light/darkness cycle of $12 \mathrm{~h}$ photoperiod, according to Simmons [35].

\subsection{Molecular Characterization of Alternaria Strains}

Ninety-two Alternaria strains, were selected for molecular characterization, among the set of strains isolated from wheat genotypes and commercial cultivars characterized.

The mycelium of three-days old fungal colonies, grown on cellophane disks overlaid on PDA plates, was collected by scraping and lyophilized.

Genomic DNA was extracted and purified from powdered lyophilized mycelia (10-15 mg) by using the "Wizard Magnetic DNA Purification System for Food" kit (Promega Corporation, Madison, WI), according to the manufacture's protocol. Quantity and integrity of DNA were checked at Thermo-Scientific Nanodrop (LabX, Midland, ON, Canada) and by comparison with a standard DNA (1 kb DNA Ladder, Fermentas GmbH, St. Leon-Rot, Germany) on 0.8\% agarose gel after electrophoretic separation.

Fragments of three informative genes, alt-a1, gpd and tef, were selected for multi-locus sequence analysis of Alternaria strains and amplified with the following primer pairs: alt-for/alt-rev [41], gpd1/gpd2 [53], Alt-tef1/Alt-tef2 [14], according to PCR conditions as reported in Ramires et al. [7].

Polymerase chain reaction mixture $(15 \mu \mathrm{L})$ contained $15 \mathrm{ng}$ of DNA template, $0.45 \mu \mathrm{L}$ of each primer $(10 \mathrm{mM}), 0.3 \mu \mathrm{L}$ of dNTPs $(10 \mathrm{mM})$ and $0.075 \mu \mathrm{L}$ of Hot Master Taq DNA Polymerase $(1 \mathrm{U} / \mu \mathrm{L}$; 5 Prime).

The PCR products were visualized with UV after electrophoretic separation in 1X TAE buffer, on $1.5 \%$ agarose gel.

Sequencing of the fragments, previously purified with the enzymatic mixture Exo/FastAP (Exonuclease I, FastAP thermosensitive alkaline phosphatase, Thermo Fisher Scientific-Waltham, MA, USA) was performed with Big Dye Terminator Cycle Sequencing Ready Reaction Kit (Applied Biosystems, Foster City, CA, USA), according to the manufacturer's recommendations. Both strands were purified by filtration through Sephadex G-50 (5\%) (Sigma-Aldrich, Aldrich, Saint Louis, MO, USA) and sequenced in "ABI PRISM 3730 Genetic Analyzer" (Applied Biosystems, Foster City, CA, USA). The FASTA sequences were obtained with BioNumerics software (Applied Maths, Kortrijk, Belgium). Phylogeny analysis was carried out including even the deposited gene sequences of the reference strains, as reported in Ramires et al. [7].

Phylogenetic trees of single and combined genes were generated by using Maximum Parsimony method and bootstrap analyses (1000 replicates, removing gaps) with MEGA5 [54].

\subsection{Mycotoxin Extraction}

All 120 wheat samples, collected from each plot and tested for fungal infection were analyzed for the natural occurrence of $\mathrm{AOH}$ contamination. Only $\mathrm{AOH}$ occurrence was evaluated in order to select an indicator of the capability of the Alternaria species isolated in this study of producing mycotoxin in vivo in the field. Chemical analyses on the 92 Alternaria strains, molecularly characterized, were also carried out to evaluate the capability of Alternaria strains to produce AOH, AME, ALT and TA. According to Li 
et al. [55], all the strains were inoculated on sterilized polished rice and grown for 21 days at $25 \pm 1{ }^{\circ} \mathrm{C}$ in darkness. The cultures were then dried and powdered before mycotoxin extraction.

The method used for mycotoxins analysis is based on that described by Rubert et al. [56] with some modifications. The samples were finely ground with an Oster Classic grinder $(220-240 \mathrm{~V}, 50 / 60 \mathrm{~Hz}$, $600 \mathrm{~W}$; Madrid, Spain). Five grams of each homogenized sample was weighed in a $50 \mathrm{~mL}$ plastic tube and $25 \mathrm{~mL}$ of methanol was added. The extraction was carried out using an Ultra Ika T18 basic Ultra-turrax (Staufen, Germany) for $3 \mathrm{~min}$. The extract was centrifuged at $4000 \mathrm{rpm}$ for $5 \mathrm{~min}$ at $5{ }^{\circ} \mathrm{C}$. One $\mathrm{mL}$ of the surnatant was filtered through a $13 \mathrm{~mm} / 0.22 \mu \mathrm{m}$ nylon filter and diluted before injection into high performance liquid chromatography associated with a diode array detector (LC-DAD). All the extractions were carried out in triplicate.

\section{HPLC Analysis}

Alternariol, AME, ALT and TA were determined using Merk HPLC with a diode array detector (LC-DAD) L-7455 (Merk, Darmstadt, Germany) at $256 \mathrm{~nm}$ and Hitachi Software Model D-7000 version 4.0 was used for data analysis. A Gemini C18 column (Phenomenex, Torrance, USA) $4.6 \times 150 \mathrm{~mm}$, $3 \mu \mathrm{m}$ particle size was used as the stationary phase. The mobile phase consisted of two eluents, namely, eluent A (water with $50 \mu \mathrm{L} / \mathrm{L}$ trifluoroacetic acid) and eluent B (acetonitrile with $50 \mu \mathrm{L} / \mathrm{L}$ trifluoroacetic acid). A gradient program with a constant flow rate of $1 \mathrm{ml} / \mathrm{min}$ was used, starting with $90 \% \mathrm{~A}$ and $10 \%$ B, reaching $50 \%$ B after $15 \mathrm{~min}$ and $100 \%$ B after $20 \mathrm{~min} .100 \% \mathrm{~B}$ was maintained for $1 \mathrm{~min}$. Thereafter the gradient was returned to $10 \% \mathrm{~B}$ in $1 \mathrm{~min}$ and allowed to equilibrate for $3 \mathrm{~min}$ before the next analysis [57].

Author Contributions: Conceptualization, A.M. and S.R.; Methodology, A.M. and S.R.; Validation, M.M., S.S., S.R., G.M., A.S. and A.M.; Formal Analysis, M.M., S.S., V.G., G.M. and M.F.; Investigation, M.M., S.S., V.G., G.M. and M.F.; Resources, M.M., S.S., A.S., V.G., G.M., M.F., S.R., A.F.L. and A.M.; Data Curation, M.M., S.S., A.S., V.G. and G.M.; Writing-Original Draft Preparation, M.M., S.S. and A.M.; Writing-Review and Editing, A.M., A.S., M.M. and S.S.; Visualization, M.M., S.S. and A.M.; Supervision, A.M. and A.S.; Project Administration, A.M.; Funding Acquisition, A.F.L. and S.R. All authors have read and agreed to the published version of the manuscript.

Funding: This work was supported by the Italian Ministry of Education, University and Research (MIUR), CTN01_00230_45076 "SO.FI.A. Sostenibilità della filiera agroalimentare italiana" Cluster "CL.A.N._Cluster Agrifood Nazionale" (CTN01_00230).

Conflicts of Interest: The authors declare no conflict of interest.

\section{References}

1. FAOSTAT. Available online: www.fao.org (accessed on 25 January 2020).

2. Conner, R.L.; Davidson, J.G.N. Resistance in wheat to black point caused by Alternaria alternata and Cochliobolus satious. Can. J. Plant Sci. 1988, 68, 351-359. [CrossRef]

3. Fernandez, M.R.; Conner, R.L. Black Point and Smudge in Wheat. Prairie Soil Crop J. 2011, 4, 158-164.

4. Srivastava, J.P.; Kushwaha, G.D.; Shukla, D.N. Black point disease of wheat and its implications on seed quality. Crop Res. 2014, 47, 21-23.

5. Hudec, K.; Muchova, D. Correlation between black point symptoms and fungal infestation and seedling viability of wheat kernels. Plant Prot. Sci. 2008, 44, 138-146. [CrossRef]

6. Abdullah, S.; Atrosh, H. New Records of Fungi on Wheat Grains From Iraq. Sci. J. Univ. Zakho 2014, 2, 256-265. [CrossRef]

7. Ramires, F.A.; Masiello, M.; Somma, S.; Villani, A.; Susca, A.; Logrieco, A.F.; Luz, C.; Meca, G.; Moretti, A. Phylogeny and Mycotoxin Characterization of Alternaria Species Isolated from Wheat Grown in Tuscany, Italy. Toxins 2018, 10, 472. [CrossRef]

8. Logrieco, A.; Moretti, A.; Solfrizzo, M. Alternaria toxins and plant diseases: And overview of origin, occurrence and risks. World Mycotoxin J. 2009, 2, 129-140. [CrossRef]

9. Logrieco, A.; Bottalico, A.; Mulè, G.; Moretti, A.; Perrone, G. Epidemiology of toxigenic fungi and their associated mycotoxins for some Mediterranean crops. Eur. J. Plant Pathol. 2003, 109, 645-667. [CrossRef] 
10. EFSA CONTAM Panel (EFSA Panel on Contaminants in the Food Chain). Scientific Opinion on the risks for animal and public health related to the presence of Alternaria toxins in feed and food. Efsa J. 2011, 9, 2407. [CrossRef]

11. Arcella, D.; Eskola, M.; Gómez Ruiz, J.A. Scientific report on the dietary exposure assessment to Alternaria toxins in the European population. EFSA J. 2016, 14, 4654. [CrossRef]

12. Amatulli, M.T.; Fanelli, F.; Moretti, A.; Mulè, G.; Logrieco, A.F. Alternaria species and mycotoxins associated to black point of cereals. Mycotoxins 2013, 63, 39-46. [CrossRef]

13. Partap, M.; Solanki, V.A.; Jagdish, P.; Nathawat, B.D.S. Evaluation of wheat cultivars for resistance against Alternaria alternata and associated fungi with black point. Plant Dis. Res. 2014, 29, 170-173.

14. Somma, S.; Amatulli, M.T.; Masiello, M.; Moretti, A.; Logrieco, A.F. Alternaria species associated to wheat black point identified through a multilocus sequence approach. Int. J. Food Microbiol. 2019, 293, $34-43$. [CrossRef]

15. Woudenberg, J.H.C.; Groenewald, J.Z.; Binder, M.; Crous, P.W. Alternaria redefined. Stud Mycol. 2013, 75, 171-212. [CrossRef]

16. Woudenberg, J.H.C.; Seidl, M.F.; Groenewald, E.; de Vries, M.; Stielow, B.; Thomma, B.J.; Crous, P.W. Alternaria section Alternaria: Species, formaespeciales or pathotypes. Stud Mycol. 2015, 82, 1-21. [CrossRef]

17. Lawrence, D.P.; Gannibal, P.B.; Peever, T.L.; Dugan, F.M.; Pryor, B. Characterization of Alternaria isolates from the infectoria species-group and a new taxon from Arrhenatherum, Pseudoalternaria arrhenatheria sp. nov. Mycol. Prog. 2014, 13, 257-276. [CrossRef]

18. Perellò, A.; Moreno, M.; Sisterna, M. Alternaria infectoria species-group associated with Black point of wheat in Argentina. Plant Pathol. 2008, 57, 379. [CrossRef]

19. Poursafar, A.; Ghosta, Y.; Orina, A.S.; Gannibal, P.B.; Nikkhah, M.J.; Lawrence, D.P. Taxonomic study on Alternaria sections Infectoriae and Pseudoalternaria associated with black (sooty) head mold of wheat and barley in Iran. Mycol. Prog. 2018, 17, 343-356. [CrossRef]

20. Garganese, F.; Schena, L.; Siciliano, I.; Prigigallo, M.I.; Spadaro, D.; De Grassi, A.; Ippolito, A.; Sanzani, S.M. Characterization of Citrus-Associated Alternaria Species in Mediterranean Areas. PLoS ONE 2016, 11, e0163255. [CrossRef]

21. Simmons, E.G. Alternaria: An Identification Manual, 6th ed.; CBS Fungal Biodiversity Centre: Utrecht, The Netherlands, 2007.

22. Simmons, E.G.; Roberts, R. Alternaria themes and variations. Mycotaxon 1993, 48, 109-140.

23. Oviedo, M.S.; Sturm, M.E.; Reynoso, M.M.; Chulze, S.N.; Ramirez, M.L. Toxigenic profile and AFLP variability of Alternaria alternata and Alternaria infectoria occurring on wheat. Braz. J. Microbiol. 2013, 44, 447-455. [CrossRef] [PubMed]

24. Polizzotto, R.; Andersen, B.; Martini, M.; Grisan, S.; Assante, G.; Musetti, R. A polyphasic approach for the characterization of endophytic Alternaria strains isolated from grapevines. J. Microbiol. Methods 2012, 88, 162-171. [CrossRef] [PubMed]

25. Da Cruz Cabrala, L.; Terminiello, L.; Pinto, V.F.; Fog, K.; Patriarca, N.A. Natural occurrence of mycotoxins and toxigenic capacity of Alternaria strains from mouldy peppers. Int. J. Food Microbiol. 2016, 7, 155-160. [CrossRef] [PubMed]

26. Yekeler, H.; Bitmis, K.; Ozcelik, N.; Doymaz, M.Z.; Calta, M. Analysis of toxic effects of Alternaria toxins on oesophagus of mice by light and electron microscopy. Toxicol. Pathol. 2001, 29, 492-497. [CrossRef]

27. Siegel, D.; Feist, M.; Proske, M.; Koch, M.; Nehls, I. Degradation of the Alternaria mycotoxins alternariol, alternariol monomethyl ether, and altenuene upon bread baking. J. Agric. Food Chem. 2010, 58, 9622-9630. [CrossRef]

28. Romero Bernal, A.R.; Reynoso, C.M.; García Londoño, V.A.; Broggi, L.E.; Resnik, S.L. Alternaria toxins in Argentinean wheat, bran, and flour. Food Addit Contam Part B Surveill 2019, 12, 24-30. [CrossRef]

29. Azcarate, M.P.; Patriarca, A.; Terminiello, L.; Fernandez Pinto, V. Alternaria Toxins in Wheat during the 2004 to 2005 Argentinean Harvest. J. Food Prot. 2008, 71, 1262-1265. [CrossRef]

30. Zhao, K.; Shao, B.; Yang, D.; Li, F.; Zhu, J. Natural Occurrence of Alternaria Toxins in Wheat-Based Products and Their Dietary Exposure in China. PLoS ONE 2015, 10, e0132019. [CrossRef]

31. Xu, W.; Han, X.; Li, F.; Zhang, L. Natural Occurrence of Alternaria Toxins in the 2015 Wheat from Anhui Province, China. Toxins 2016, 8, 308. [CrossRef] 
32. Topi, D.; Tavcar-Kalcher, G.; Pavšič-Vrtač, K.; Babič, J.; Jakovac-Strajn, B. Alternaria mycotoxins in grains from Albania: Alternariol, alternariol monomethyl ether, tenuazonic acid and tentoxin. World Mycotoxin J. 2019, 12, 89-99. [CrossRef]

33. Wenderoth, M.; Garganese, F.; Schmidt-Heydt, M.; Soukup, S.T.; Ippolito, A.; Sanzani, S.M.; Fischer, R. Alternariol as virulence and colonization factor of Alternaria alternata during plant infection. Mol. Microbiol. 2019, 112, 131-146. [CrossRef]

34. Rozen, S.; Skaletsky, H. Primer3 on the WWW for general users and for biologist programmers. Methods Mol. Biol. 2000, 132, 365-386. [CrossRef] [PubMed]

35. Avenot, H.F.; Michailides, T.J. Resistance to boscalid fungicide in Alternaria alternata isolates from pistachio in California. Plant Dis. 2007, 91, 1345-1350. [CrossRef] [PubMed]

36. Greco, M.; Patriarca, A.; Terminiello, L.; Fernández Pinto, V.; Pose, G. Toxigenic Alternaria species from Argentinean blueberries. Int. J. Food Microbiol. 2012, 154, 187-191. [CrossRef]

37. Andersen, B.; Hansen, M.E.; Smedsgaard, J. Automated and unbiased image analyses as tool in phenotypic classification of small-spored Alternaria spp. Phytopathology 2005, 95, 1021-1029. [CrossRef]

38. Andersen, B.; Dongo, A.; Pryor, B.M. Secondary metabolite profiling of Alternaria dauci, A. porri, A. solani and A. tomatophila. Mycol. Res. 2008, 112, 241-250. [CrossRef]

39. Brun, S.; Madrid, H.; Van Den Ende, B.G.; Andersen, B.; Marinach-Patrice, C.; Mazier, D. Multilocus phylogeny and MALDI-TOF analysis of the plant pathogenic species Alternaria dauci and relatives. Fungal Biol. 2013, 117, 32-40. [CrossRef]

40. Chou, H.H.; Wu, W.S. Phylogenetic analysis of internal transcribed spacer regions of the genus Alternaria, and the significance of filament-beaked conidia. Mycol. Res. 2002, 106, 164-169. [CrossRef]

41. Hong, S.G.; Cramer, R.A.; Lawrence, C.B.; Pryor, B.M. Alt a1 allergen homologs from Alternaria and related taxa: Analysis of phylogenetic content and secondary structure. Fungal Genet. Biol. 2005, 42, 119-129. [CrossRef]

42. Inderbitzin, P.; Shoemaker, R.A.; O'Neill, N.R.; Turgeon, B.G.; Berbee, M.L. Systematics and mating systems of two fungal pathogens of opium poppy: The heterothallic Crivellia papaveracea with a Brachycladium penicillatum asexual state and a homotallic species with a Brachycladium papaveris asexual state. Can. J. Bot. 2006, 84, 1304-1326. [CrossRef]

43. Pryor, B.M.; Creamer, R.; Shoemaker, R.A.; McLain-Romero, J.; Hambleton, S. Undifilum, a new genus for endophytic Embellisia oxytropis and parasitic Helminthosporium bornmuelleri on legumes. Botany 2009, 87, 178-194. [CrossRef]

44. Runa, M.; Park, M.; Pryor, B. Ulocladium systematics revisited: Phylogeny and taxonomic status. Mycol. Prog. 2009, 8, 35-47. [CrossRef]

45. Somma, S.; Pose, G.; Pardo, A.; Mulè, G.; Pinto, V.F.; Moretti, A.; Logrieco, A.F. AFLP variability, toxin production and pathogenicity of Alternaria species from Argentinian tomato fruits and puree. Int. J. Food Microbiol. 2011, 145, 414-419. [CrossRef] [PubMed]

46. Pryor, B.M.; Michailides, T. Morphological, Pathogenic, and Molecular Characterization of Alternaria Isolates Associated with Alternaria Late Blight of Pistachio. Phytopathology 2002, 92, 406-416. [CrossRef]

47. Patriarca, A.; Azcarate, M.P.; Terminiello, L.; Fernández Pinto, V. Mycotoxin production by Alternaria strains isolated from Argentinean wheat. Int. J. Food Microbiol. 2007, 119, 219-222. [CrossRef]

48. Gargouri-Kammoun, L.; Bensassi, F.; Mnari-Hattab, M.; Rhouma, A.; Bacha, H.; Hajlaoui, M.R. Identification of Alternaria Species Recovered from Stored Durum Wheat Kernels in Tunisia. Tunis. J. Plant Prot. 2014, 9 , 119-129.

49. Kahl, S.M.; Ulrich, A.; Kirichenko, A.A.; Muller, M.E.H. Phenotypic and phylogenetic segregation of Alternaria infectoria from small-spored Alternaria species isolated from wheat in Germany and Russia. J. Appl. Microbiol. 2015, 119, 1637-1650. [CrossRef]

50. Kosiak, B.; Torp, M.; Skjerve, E.; Andersen, B. Alternaria and Fusarium in Norwegian grains of reduced quality-A matched pair sample study. Int. J. Food Microbiol. 2004, 93, 51-62. [CrossRef]

51. Müller, M.E.H.; Korn, U. Alternaria mycotoxins in wheat-A 10 years survey in the Northeast of Germany. Food Control 2013, 34, 191-197. [CrossRef]

52. Liu, G.T.; Qian, Y.Z.; Zhang, P.; Dong, Z.M.; Shi, Z.Y.; Zhen, Y.Z.; Miao, J.; Xu, Y.M. Relationships between Alternaria alternata and oesophageal cancer. IARC Sci. Publ. 1991, 105, 258-262. 
53. Berbee, M.L.; Pirseyedi, M.; Hubbard, S. Cochliobolus phylogenetics and the origin of known, highly virulent pathogens, inferred from ITS and glyceraldehyde-3-phosphate dehydrogenase gene sequences. Mycologia 1999, 91, 964-977. [CrossRef]

54. Tamura, K.; Peterson, D.; Peterson, N.; Stecher, G.; Nei, M.; Kumar, S. MEGA5: Molecular Evolutionary Genetics Analysis Using Maximum Likelihood, Evolutionary Distance, and Maximum Parsimony Methods. Mo. Biol. Evol. 2011, 28, 2731-2739. [CrossRef]

55. Li, F.Q.; Toyazaki, N.; Yoshizawa, T. Production of Alternaria mycotoxins by Alternaria alternata isolated from weather-damaged wheat. J. Food Prot. 2001, 64, 567-571. [CrossRef]

56. Rubert, J.; Dzuman, Z.; Vaclavikova, M.; Zachariasova, M.; Soler, C.; Hajslova, J. Analysis of mycotoxins in barley using ultra high liquid chromatography high resolution mass spectrometry: Comparison of efficiency and efficacy of different extraction procedures. Talanta 2012, 99, 712-719. [CrossRef]

57. Myresiotis, C.K.; Testempasis, S.; Vryzas, Z.; Karaoglanidis, G.S.; Papadopoulou-Mourkidou, E. Determination of mycotoxins in pomegranate fruits and juices using a QuEChERS-based method. Food Chem. 2015, 182, 81-88. [CrossRef]

(C) 2020 by the authors. Licensee MDPI, Basel, Switzerland. This article is an open access article distributed under the terms and conditions of the Creative Commons Attribution (CC BY) license (http://creativecommons.org/licenses/by/4.0/). 